\title{
An Investigation into the Challenges Facing Administration of STEM Education in Gwagwalada Universal Basic Education Junior Secondary Schools in FCT, Nigeria
}

\author{
Ogunode Niyi Jacob \\ Federal University, Wukari, Nigeria \\ ogunodejacob@gmail.com
}

\begin{abstract}
This study aimed to investigate the challenges facing the administration of STEM Education in Gwgwalada junior secondary schools of FCT, Nigeria. The study employed a descriptive survey design. The instruments used for data collection were questionnaires titled:' Challenges facing Administration of STEM Education Questionnaire" (CFASEQ). The sample for the study comprised of 200 teachers. A simple random sampling method was used to select the sample. One hypothesis and three research instruments were used for the study. Test and retest were employed to determine the reliability of the instrument. Simple percentages were employed to analyze the data collected and a chi-square test was used to test the hypothesis. The study revealed that challenges are facing the administrations of STEM Education in Gwagwalada junior secondary schools and these challenges include; inadequate infrastructural facilities, shortage of science teachers, lack of instructional materials, lack of motivation, inadequate fund, poor supervision, high population, poor capacity development program for science teachers and negative attitude of students towards STEM education. The result also revealed that $100 \%$ of the respondents agreed that the implications of the challenge facing the administration of STEM Education are responsible for poor implementation of STEM education in Gwagwalada junior secondary schools of FCT, Nigeria. From the finding, it was recommended that the government increase the funding of education and give more priority to STEM Education.
\end{abstract}

Keywords:

Challenges, Administration, STEM Education

\section{INTRODUCTION}

Nigeria, the giant of Africa from an estimated 42.5 million people at the time of independence in 1960 now is Africa's most populous country with a population of $188,462,640$ people, making it the seventh most populous country in the world. It is located in West Africa. Nigeria has a federal system of government with 36 States and Abuja as the Federal Capital
Territory and 744 local government councils. Nigeria is multilingual and is home to about 250 different ethnic groups. The official language is the English language and she has three major languages of the largest groups, the Hausa, the Ibo, and Yoruba. The official currency is the Naira.

The educational system in Nigeria is divided into three major forms: basic school 
education, secondary school education, and higher education. The duration for the basic education is nine years, -senior secondary school education is three years and four to six years for higher education depending on the discipline.

Basic education is compulsory and free for all Nigerian children. The starting age is six and its duration is six years for the primary school's section and three years duration for the junior secondary school. The following subjects are taken in the basic school; mathematics program, English program, religious knowledge program, basic science program, and technology program, and students will choose one out of the three major Nigerian languages (Hausa, Igbo, and Yoruba). The objectives of basic education in Nigeria include functional literacy and numeracy, develop the ability to communicate effectively, and enhance positive attitudes towards cooperation, work, community, national development, and continuous learning. In Nigeria, children are expected to have a continuous, uninterrupted stretch of education for nine years from primary school to the third year of the junior secondary school.

The junior secondary school in Nigeria consists of three years. It is post-basic school education. The junior secondary school curriculum is both academic and pre-vocational. It is meant to prepare the pupils to acquire further knowledge and develop skills. The subjects offered here include English language, French, mathematics, integrated science social studies and citizenship education, and introduction to technology. Students are expected to choose one Nigerian language. The electives for pre-vocational include, home economics, agriculture, business studies, computer education, and local crafts. The Non-prevocational electives subjects are creative arts (music and fine art), Arabic, physical and health education, and religious and moral education. Students at the junior secondary schools are expected to take a minimum of 10 and a maximum of 13 subjects, including all the core subjects. To be promoted to the senior secondary school section, students must be assessed through tests and sit for junior secondary school examinations.

Administration and management of education in Nigeria have shared responsibilities between the Federal government, state government, and the local government. In Nigeria's constitution, the educational sector is on the concurrent list. The Federal government of Nigeria can regulate all the educational sectors through the making of educational policy and control of quality. The three-tier of government is allowed by the constitution 
to handle its educational sector. Higher education is handle by the Federal Government. Secondary education is in the hand of the state government and primary education is handled by the local governments. Despite this arrangement, the Federal Government is expected to support the state and local governments in counterpart funding to enhance the quality of education in the country. The Federal government of Nigeria is constitutional bind to support the development of education at the state level and local government level by providing counterpart funding for education in the country.

In Nigeria, the administration of the education system is shared among different education ministries in the country at both the federal government level and the state government. The federal government established some agencies and commission under the federal ministry of education and they are charged with different responsibilities. The function of the Federal Ministry of Education is for the coherence of the national policy and procedures and for ensuring that the states' policies operate within the parameters of the national policy as adapted for local needs.

In Nigeria, the National Council of Education is the highest policymaking body chaired by the Federal Minister of Education and includes all the State
Commissioners of Education from each state. They coordinate planning, policy formulation at the political level. The National Council of Education is advised by the Joint Consultative Committee on Education, which made up of all the Federal Directors of Education and State Directors of Education, Chief Executives of education statutory bodies, and Directors of University Institutes of Education. The State Universal Basic Education Board (SUBEB) was established to assists the state government in the administration of primary schools.

According to the Nigerian constitution the Local Government is saddled with the responsibility of basic school administration through the Local Government Education Authorities (LGEA). The functions of Local Government Education Authorities (LGEA) are as follows:

a. Government policy interpretation for easier and effective administration and management of schools;

b. Storing and keeping of primary school teachers' confidential reports and record of service;

c. Primary school teachers' salaries and allowances payment;

d. Approval of Local contribution for educational development; and

e. Request for financial aid from the State government. 
The Nigeria government also general. Every individual on the planet established an agency called Universal earth has felt the positive impact of STEM. Basic Education Commission (UBEC) STEM education is part of the universal which is a national federal government basic education program in Nigeria. STEM agency that handles the administration of subjects are offered from the basic schools primary education. The Commission helps and junior secondary schools. The objective in the counterpart funding and management of basic education in the Country. Basic education administration and management at the school level involved the school administrator/headmaster. $\mathrm{He} / \mathrm{She}$ is appointed by the government to head the schools. HE/ she is assisted by an assistant headmaster/headmistress. The headmaster is saddled with the responsibility of the planning, organizing, directing, and coordinating all the activities of the schools including the teachers and pupils. The head is assisted by an assistant headteacher in his/her daily administration of the school. Teachers are at the instructional delivery level in the classroom.

STEM education is part and parcel of the Nigerian educational system for long. STEM which implies Science, Technology, Engineering, and Mathematics (STEM). The importance of STEM education as a means for economic, social, political development, and technological advancement of a nation cannot be underestimated. The STEM education has contributed a lot to the economic, social, industrial life of Nigeria and in the world in of STEM Education is to make the teaching and learning of technology, engineering, and mathematics. These teaching commonly include all education-related activities across all grade levels starting from pre-school up to post-doctoral levels. These could also be either informal, formal setting, or both. As a basis for the different emerging technologies, the role of STEM is crucial to the development of any economy.

STEM education is the bedrock of innovative and highly productive future workforces, integral to the economic development of the continent. In line with this, the African Union Agenda 2063, identifies one of its goals as raising welleducated citizens and skills revolution underpinned by Science, Technology, and Innovation. Nigeria's government has initiated many arrangements and has done many collaborative programs with the objectives of drawing from the technological experience of many developed countries to build its STEM education program for its teeming youths across the country especially those in the educational institutions. These partnerships 
have been made with both individual countries and international development organizations. It is observed by (Ikeobi, 2010) that the US-based Global Partnership of Education has given Nigeria more than USD100 million in grants to raise the quality of education, with an emphasis on the underdeveloped northern regions of the country. In 2017, the US announced the creation of an education academy that functions as a robotics-training suite for more than 450 Nigerian students as well as a general STEM education center for teachers and researchers.

The teaching and learning of STEM education in Nigeria, in Abuja and Gwagwalada junior secondary schools are plagued with many challenges. Few studies have examined the challenges facing the teaching and learning of STEM education at the primary school level and junior secondary schools level too in Nigeria. Moreover, there is no available evidence of studies on the challenges facing the administration of STEM education at the junior secondary schools level in Gwagwalada area council of FCT, Nigeria. This study aims to close this research gap by investigating the challenges facing the administration of STEM education in Gwagwalada junior Secondary Schools of FCT, Nigeria.

\section{LITERATURE REVIEW}

1. Concept of Educational Administration Educational administration means different things to different people. Educational administration is a process that involves planning, organizing, directing, coordinating, and controlling both human and materials resources to achieve educational objectives. In the school system, the administrator is the head. The administrator is responsible for managing the students, teachers and educational inputs to ensure the defined goals are realized within the set time. Educational administration can also be defined as the systematic arrangement of the human resources and material resources and an effective and efficient user of limited educational resources to attain the educational institution objectives within a set time. The roles of the administrator are planning, organizing, controlling, directing, and supervising various activities to ensure that the institutions achieve their goals at the end. Education administration also involves the application of human and material resources within the school's institutions to achieve the broad goals of the educational institutions. It involves designing programs, policies, and implementing them rightly and timely. 
2. Meaning of STEM Education

STEM was once referred to as Science, Technology, and Society (STS) in the distant past. Its emergence in the classroom is to train individuals with up to date knowledge in the affiliated disciplines to meet the current demand of the society and to shift the limit of human thinking and problem-solving ability which may result in meaningful development and improved living.

Historically, Science, Technology, Engineering, and Mathematics, predates its classroom teaching. Its application also existed before formalizing the approach in learning. Each of these fields and disciplines affiliated is now being studied from the most elementary stage of classroom teaching to the highest level of formal education in the developed world. Although STEM education remains a challenge to some developing countries in Africa (Olalekan, 2018).

STEM is the combination of sciences subjects like science programme, technology programme, engineering programme, and mathematics programme as knowledge in one single unit. These various disciplines are resources for learning and invention and are seen as relevant, significant, and inert-related. Education in STEM as a transdisciplinary field is old, but the knowledge integration may serve as a resource to enrich learners and make sense of the world rather than observing through narrow inter-disciplinary lenses. STEM education could still be said to have challenges that are not only students related, rather, peculiar hindrances encountered by teachers of STEM in developing countries (Veral, 2018).

There are many objectives of STEM education. (Aguele \& Agwagah, 2007) States that STEM Education is expected to serve as a basic supply of manpower to industrial communities towards the achievement of virile economic and national development. Specifically, in my designs and the possibility of self-reliance, STEM hopes to engender socio-economic development through the opportunity for employment, income benefit, and welfare improvement. It is meant to foster scientific skills and capability and habit to solve problems coupled with imaginative creative thinking and general mental prowess. However, it is obvious that, as of today, these lofty goals (of STEM) cannot be said to have been satisfactorily achieved in most developing countries, especially Nigeria, consider the level of development and massive unemployment of graduates, the supposedly 'STEMmed' technocrats.

(Emmanuel, et.al, 2019) Observed that STEM has since been enjoying good and massive support from both governments 
and other stakeholders in terms of funding, scholarships, and availability of facilities. STEM education approach is to spur a revolution in the academic curriculum through the teaching of subjects such as mathematics and science with bias in technology and engineering. It is meant to drive a student's capability to solve problems, discover, and explore. It is a key to transform the traditional typical teachercentered classroom into a problem-solving meeting of the students and the teachers. According to (Gonzalez \& Kuenzi (2012), the STEM approach allows students to think critically, apply the skills learned, and explore in-depth the problem covered towards providing solutions to the problem.

The importance of STEM education to technological development cannot be overemphasized that why (Bisi, 2012) submitted that science education promotes the total development of the country. It has a link to the economic, political, and social development of a nation. Science education action can inform choices about how technology is used to enhance the current living conditions for humans and other living things. Science education encourages learners to reason critically to make decisions that are well informed. There are no shortcomings in science education, good knowledge of scientific principles, and facts are vital for a comprehensive education
(Harri, 2011). Although there has been a tremendous increase in the net enrolment of learners, the question is whether this increase has translated to qualitative education (Emechebe, 2012).

There have been many challenges in teaching STEM education in Nigerian junior secondary schools. (Bisi, 2012) I also observed that the teaching and learning of basic science have shown several challenges.

1. Shortage of science instructional materials.

2. Inadequate professional teachers for basic science subjects.

3. Poor supervision of science programme

4. Inadequate infrastructural facilities.

Several researchers have researched STEM Education and science education in Nigeria. (Emmanuel, et.al, 2019) Did study on demographic trends and growth as the main engine for technological progress. The study portrays demographic trends as a crucial engine for technological progress and also works as the drivers of human capital towards the achievement of economic prosperity. The result revealed a wider gender gap that ranges from $41.4 \%$ to $51.5 \%$ in both pre-and-post- STEM policy, though it finally established at $41.5 \%$ in 2009. The study positioned demographers as the conduit for delivery of optimum population or population explosion via 
assisted fertility technology e.g. in-vitro fertilization (IVF), pre-implantation genetic diagnosis, human reproductive cloning, fetal DNA in maternal plasma, and genetic diagnosis). Therefore, while the pursuit of science programme, technology programme, engineering programme, and mathematics programme is crucial for growth, the neglect of the sources of supply of human drivers or the demographic-based pull-and-push factors could engender wobbling and crawling structure of technological advancement. The authors recommend adequate knowledge of these interplays for plausible.

Research on problems and prospects in the learning of basic science in the upper basic under the umbrella of the Universal Basic Education program was carried by (Christine \& Hayatu, 2014). The purpose of the study was to assess the UBE program in Nigeria. (Christine \& Hayatu, 2014) Developed six research instruments used for the research. A descriptive survey design method was employed. The target population was 20,000 students and 150 teachers. A random selection gave a sample of 200 students and 15 teachers. Two sets of questionnaires were employed. The simple percentage was adopted for data analysis. The results revealed that the teaching and learning of basic science in the upper basic in Kajuru Local Government
Area of Kaduna State has some problems such as lack of qualified and competent teachers, high enrolment of students with lack of adequate facilities. (Emechebe, 2012)

From the above literature reviewed, it is obvious that there has not been researching on the challenges facing the administration of STEM education in Gwagwalada junior secondary schools of FCT, Nigeria. This study aims to investigate the challenges facing the administration of STEM education in Gwagwalada junior secondary schools of FCT, Nigeria.

\section{RESEARCH QUESTION}

The researcher developed the below research questions for the research:

1. Are there challenges facing the administration of STEM education in Gwagwalada junior secondary schools of FCT?

2. What are the challenges facing administration on STEM education in Gwagwalada junior secondary schools of FCT?

3. What are the implications of the challenges on STEM education implementation in Gwagwalada junior secondary schools of FCT? 


\section{A. Research Objectives}

The purpose of this research is to investigate the challenges facing the administration of STEM education in Gwagwalade universal basic education junior secondary schools. The sub-objective of the research includes:

1. To establish if challenges are facing the administration of STEM education in Gwagwalada junior secondary schools.

2. To find out the challenges facing administration STEM education in Gwagwalada junior secondary schools.

3. To find out the implication of the challenges on STEM education implementation in Gwagwalada junior secondary schools.

\section{B. Research Hypothesis}

Following the research question for this research, the researcher developed the following hypothesis to guide this research. Ho: There is no significant relationship between administrative challenges and STEM education in Gwagwalada junior secondary schools.

H1: There is a significant relationship between administrative challenges and STEM education in Gwagwalada junior secondary schools.

\section{RESEARCH METHOD}

The purpose of this research is to investigate the challenges facing the Administration of STEM Education. The study adopted a descriptive survey design. All the teachers of universal basic education junior secondary school in Abuja were population for the study. The target population comprised twenty school administrators and one hundred and eighty teachers selected from five universal basic education junior secondary schools across the Gwagwalada area council of FCT, Abuja, Nigeria totaling two hundred respondents. A simple random sampling technique was used to select the sample of the research.

The instrument used for data collection was Questionnaire and it was titled "Challenges facing Administration of STEM Education Questionnaire" (CFASEQ). The questions designed for the study were cross-checked by researchers from the University of, Abuja. Their input and observation were taken into effect. The questionnaire was made up of two sections. Section one which was titled A dealt with the collection of bio-data information of the respondents while section two which was also titled section $\mathrm{B}$ collected data on the topic of the research.

The researcher developed one hypothesis and three research questions for 
the research work and one hypothesis. The the Kwali area council of FCT. The researcher used a 4-point Likert scale respondents were administered the questionnaire option with the following questionnaire to their institutions and the features: Strongly agree [4], Agree [3], questionnaires were returned to the Disagree [2], and Strongly Disagree [1]. researcher. Data collected were analyzed The test re-test method was used to confirm using simple percentages and chi-square the reliability of the research instrument. tests.

Ten [10] teachers in universal basic education junior secondary school in the

RESULT ANALYSIS

AND Kwali area council were given 10 copies of the research questions and it was retrieved within 10 working days. The same questions were re-administered by the

\section{DISCUSSION}

Question One: Are there challenges facing the administration of STEM Education? researchers to the same ten teachers from

Table 1. Responses on if challenges are facing the administration of STEM Education.

\begin{tabular}{|l|l|l|l|l|l|l|l|l|}
\hline S/N & Items & $\begin{array}{l}\text { Strongly } \\
\text { Agree }\end{array}$ & Agree & $\%$ & Disagree & $\begin{array}{l}\text { Strongly } \\
\text { Disagree }\end{array}$ & Total \\
\hline 1 & $\begin{array}{l}\text { Are there challenges facing the } \\
\text { administration of STEM } \\
\text { Education? }\end{array}$ & 176 & 24 & 100 & - & - & - & 200 \\
\hline
\end{tabular}

Results collected on table one item one reveals that $176(88 \%)$ of the respondents agreed that their challenges facing the administration of STEM education while 24 $(12 \%)$ of the respondents disagreed. This implies that the majority of the sampled respondent agreed that STEM education in Gwagwalada junior secondary schools is facing a lot of challenges in FCT.

Research Question Two: What are the challenges facing the administration of
STEM education in Gwagwalada junior secondary schools?

Result obtained from table two-item one shows that $83(41.5 \%)$ ticked strongly agree, $64(32 \%)$ ticked agree that inadequate infrastructural facilities are one of the challenges facing the administration of STEM education while $31(15.5 \%)$ of the respondents strongly disagreed and $22(11 \%)$ disagreed. This means that the majority of the respondents agreed that inadequate infrastructural facilities are 
among the challenges facing the (Christine \& Hayatu, 2014) who revealed in administration of STEM education in their study that the availability of facilities Gwagwalada junior secondary schools. This such as classrooms, laboratories, result is in agreement with the submission workshops, and instructional

Table 2. Responses on if challenges challenges facing the administration of STEM education in Gwagwalada junior secondary schools

\begin{tabular}{|c|l|c|c|c|c|c|c|c|}
\hline S/N & $\begin{array}{l}\text { The following are } \\
\text { challenges facing the } \\
\text { administration of STEM } \\
\text { education in Universal } \\
\text { Basic Education Junior } \\
\text { Secondary Schools }\end{array}$ & $\begin{array}{l}\text { Agree } \\
\text { Strongly }\end{array}$ & Agree & $\%$ & Disagree & $\begin{array}{c}\text { Strongly } \\
\text { Disagree }\end{array}$ & $\%$ & Total \\
\hline 1 & $\begin{array}{l}\text { Inadequate } \\
\text { infrastructural facilities }\end{array}$ & 83 & 64 & 73.5 & 31 & 22 & 26.5 & 200 \\
\hline 2 & $\begin{array}{l}\text { Inadequate science } \\
\text { teachers }\end{array}$ & 63 & 70 & 66.5 & 42 & 25 & 33.5 & 200 \\
\hline 3 & $\begin{array}{l}\text { Lack of instructional } \\
\text { materials }\end{array}$ & 72 & 84 & 78 & 30 & 14 & 22 & 200 \\
\hline 4 & $\begin{array}{l}\text { Poor supervision and } \\
\text { inspection }\end{array}$ & 59 & 66 & 62.5 & 45 & 30 & 37.5 & 200 \\
\hline 5 & \begin{tabular}{l} 
Lack of Motivation \\
\hline 6
\end{tabular} & 53 & 67 & 60 & 44 & 36 & 40 & \\
\hline 7 & $\begin{array}{l}\text { Inadequate fund } \\
\text { High Population }\end{array}$ & 83 & 92 & 87.5 & 15 & 10 & 12.5 & 200 \\
\hline 8 & $\begin{array}{l}\text { The poor capacity } \\
\text { development program for } \\
\text { science teacher }\end{array}$ & 106 & 81 & 93.5 & 9 & 4 & 6.5 & 200 \\
\hline $\begin{array}{l}\text { The negative attitude of } \\
\text { Ste student toward } \\
\text { STEM Programme }\end{array}$ & 103 & 77 & 90 & 13 & 7 & 10 & 200 \\
\hline
\end{tabular}

aides in the upper basic. $73.3 \%$ of the teacher relied basically on the blackboard, teachers strongly agree that there are no chalk, and archaic textbooks.

adequate classrooms nor laboratories or

Result obtained from table two-item workshops. $26.7 \%$ of teachers agree that two shows that $63(31.5 \%)$ of the instructional aids are inadequate. The respondents ticked strongly agree $70(35 \%)$ of the respondents ticked agree that 
inadequate science teachers are one of the challenges facing the administration of STEM education while 42(21\%) ticked strongly disagree and $25(12.5 \%)$ ticked disagree. This means that the majority of the respondents agreed that inadequate science teachers are among the challenges facing the administration of STEM education in Gwagwalada junior secondary schools. This result agrees with the result of (Christine \& Hayatu, 2014) who revealed $93.3 \%$ of the UBE teachers strongly disagree that the number of trained teachers teaching on the UBE program is adequate. $6.7 \%$ of the teachers disagree that they are adequate and qualified staff on the UBE program.

Result obtained from table two item three shows that $72(36 \%)$ of the respondents strongly agreed, 84(42\%) of the respondents agreed that lack of instructional materials is one of the challenges facing the administration of STEM education while $30(15 \%)$ of the respondents strongly disagreed and 14 (7\%) disagreed. This means that the majority of the respondents agreed that a lack of instructional materials is among the challenges facing the administration of STEM education in Gwagwalada junior secondary schools. This result confirms the finding of (Future of Education Summit, 2020) who disclosed that almost all secondary schools in Nigeria lack science materials, and those that claim to have are managing the old ones. He went further to submit that students only cram theoretical steps rather than carrying out the practical. Also, many schools and colleges have buildings that they call libraries, but most of these so-called libraries are not equipped with needed books, journals, and magazines.

Result obtained from table two-item four discloses that 59(29.5\%) ticked strongly agree, 66(33\%) ticked agree while $30(15 \%)$ ticked disagree and 45(22.5\%) ticked strongly disagree that poor supervision and inspection is one of the challenges facing the administration of STEM education. This means that the majority of the respondents agreed that poor supervision and inspection are among the challenges facing the administration of STEM education in Gwagwalada junior secondary schools. This result is in line with the result of (Musa, 2016) who submitted that the supervision of basic schools in Nigeria is not effective.

Result obtained from table two-item five reveals that 53(26.5\%) ticked strongly agree, 67(33.5\%) ticked agree, 44(22\%) ticked disagree and 36 (18\%) ticked strongly disagree that lack of motivation of science teachers is among of the challenges facing the administration of STEM 
education. This means that the majority of the respondents agreed that the lack of motivation of science teachers is among the challenges facing the administration of STEM education in Gwagwalada junior secondary schools. This result supports the findings of (Adelabu. 2005) found in Nigeria that teacher's motivation is very poor and teachers are also dissatisfied with their working environment and salary conditions. The reason behind the poor motivation of teachers is that they having low salaries as compared to other professionals, poor work environment, no decision making authority, and also not allowing them to develop their career.

Results obtained from table two-item six shows that (105\%) went for strongly agree, and (95\%) agreed that inadequate funding is among the major challenges facing the administration of STEM education. This means that $100 \%$ of the people sampled agreed that inadequate funding is one of the challenges facing the STEM program administration in Gwagwalada junior secondary schools. This result is in agreement with (Bisi, 2012) who opines that funding is a major problem facing STEM education programs in Nigeria.

Result obtained from table two-item seven shows that $83(41.5 \%)$ ticked strongly agree and 92(46\%) ticked agree while
$10(5 \%)$ of the people sampled ticked disagree and $15(7.5 \%)$ went for strongly disagree that high population is one of the challenges facing the administration of STEM education. This means that almost all the sampled people agree that a high population is among the challenges facing the STEM administration in Gwagwalada junior secondary schools. According to the UNESCO teacher-student ratio of 1:35 is recommended for secondary schools but in Nigeria's secondary schools is not so. [14] Submitted that the population of Nigeria has grown to about 140 million. The growth of the Nigerian population has influenced student population and class size. Most secondary schools within Abuja Federal Capital Territory (FCT) and Zaria metropolis in Kaduna state have a teacherstudent ratio between $1: 100$ and 1:130 per class. (Ugo \& Akpoghol, 2016)

The result obtained from table twoitem eight shows that $106(53 \%)$ of the respondents strongly agreed and $81(40.5 \%)$ of the respondents agreed while 9(4.5\%) disagreed and $4(2 \%)$ strongly disagreed that poor capacity development programme for science teacher is one of the challenges facing the administration of STEM education. This means that the majorities of the respondents agreed that poor capacity development programme for science teacher is a major challenge facing the 
administration of STEM education in challenges facing the administration of Gwagwalada junior secondary schools. This result is in line with (Abubakar, 2015) who STEM education. This means that the submitted that teachers in Nigeria lack capacity development programme for effective teaching in the school.

Table two-item nine shows that $103(51.5 \%)$ ticked strongly agree and 77 (38.5\%) ticked agree while $13(6.5 \%)$ ticked disagree and $7(3.5 \%)$ ticked strongly disagree that negative attitude of students towards STEM programme is one of the majority of the respondents agreed that the negative attitude of students towards STEM programme is a major challenge facing the administration of STEM education in UBE junior secondary schools in Gwagwalada area council of FCT. This result is in agreement with the findings of (Abubakar, 2015) who discovered that majorities of students have a negative attitude towards science programs in secondary schools.

Table 3 Responses to the implication of challenges on the implementation of STEM education in Gwagwalada junior secondary schools.

\begin{tabular}{|l|l|l|l|l|l|l|l|l|}
\hline S/N & $\begin{array}{l}\text { The following are the Strongly } \\
\text { implications of the challenges on } \\
\text { Agree }\end{array}$ & $\%$ & Disagree & $\begin{array}{l}\text { Strongly } \\
\text { Disagree }\end{array}$ & Total \\
\hline 1 & $\begin{array}{l}\text { Poor implementation of STEM } \\
\text { education }\end{array}$ & 59 & 100 & - & - & - & 200 \\
\hline
\end{tabular}

Data obtained from table three-item one shows that $200(100 \%)$ of the respondents agreed that the implications of challenges facing the planning and administration of STEM education are resulting in poor implementation of STEM education in Gwagwalada junior secondary schools of fct, Nigeria.

\section{Hypothesis Testing}

Ho: There is no significant relationship between administrative challenges and STEM education in Gwagwalada junior secondary schools.
H1: There is a significant relationship between administrative challenges and STEM education in Gwagwalada junior secondary schools. The result collected from the table showed that the table value of 0.195 is less than the $r$ calculated value of 0.926. Thus, meaning that there is a significant relationship between administrative challenges and STEM education in Gwagwalada junior secondary schools. The hypothesis which states that there is no significant relationship between administrative challenges and STEM education in Gwagwalada junior secondary 
Table 4. Hypotest Result

\begin{tabular}{|lccccc|}
\hline Variable & N & DF & t-Calculated & t-Critical & Result \\
\hline X & 200 & & & & \\
\hline Y & 200 & 198 & 0.926 & 0.195 & \\
\hline & & & & & Significant \\
\hline
\end{tabular}

schools is rejected.

\section{CONCLUSION AND RECOMMENDATION}

The purpose of the research was to investigate the challenges facing the administration of STEM education in Gwagwalade junior secondary schools of universal basic education.

The result of the study indicates that challenges are facing the administrations of STEM education programme in Gwagwalada junior secondary schools and these challenges include; inadequate infrastructural facilities, shortage of science teachers, lack of instructional materials, lack of motivation, inadequate fund, poor supervision, high population, poor capacity development programme for science teachers and negative attitude of students towards STEM education programme. This result also revealed that the majority of the respondents agreed that the implications of the challenge facing the administration of
STEM education is resulting in poor implementation of STEM education in Gwagwalada junior secondary schools of FCT, Nigeria.

From the result collected, the researcher hereby recommends the following:

1. The government should increase the funding of education and give more priority to STEM Education.

2. The government should employ more science teachers and deploy them to all the junior secondary schools across FCT.

3. The government should provide more infrastructural facilities in all the junior secondary school. This will help to reduce the large class size and teachers will have access to adequate offices.

4. The government should provide instructional material on STEM to all the junior secondary schools in FCT.

5. The government should fight all forms of corruption in the ministry of education by employing an effective monitoring 
mechanism. This will help to reduce the case of diversion of education funds.

6. The government should ensure capacity development programme are constantly organized for the STEM teachers to improve their teaching skills and methodologies

7. The government to ensure effective supervision of stem education programme to improve the quality

\section{REFERENCES}

Ikeobi, I.O (2010). Beyond the stereotype: Thoughts and reflections on education. Yaba: the CIBN Press Limited.

Olalekan B.,(2018). Evolution of STEM, STEAM and STREAM Education in Africa: The Implication of the Knowledge Gap. https://www.researchgate.net/publicat ion/1GV9Jm2u7rmsCe65wKzPTw5jt S38n2tVEGind_STREGV9Jm2u7rms Ce65wKzPTw5jtS38n2tVEGition_of _the_Knowledge_Gap

Veral, T.S. (2018). Global partnership for education. Lagos

Aguele LI \&\& Agwagah UN.( 2007). Female participation in science, technology and mathematics (STM) education in Nigeria and national development. Journal Soc Sci;15(2):121-6.
Emmanuel O., Paul, O,. A, Adebanke O, I, Gbemisola W, S, Moses A. A, Mofoluwake, P, A, Olasunmbo O, A, (2019). Science, Technology, Engineering and Mathematics: Where is the Place of Demography? A Position Paper on Demography and STEM, International Journal of Mechanical Engineering and Technology 10(2), pp. 187-197.

Gonzalez \& Kuenzi (2012). Science, technology, engineering, and mathematics (STEM) education: A primer. In Congressional Research Service, Library of Congress; 2012 [cited 2018 Dec 27]. Available from: http://www.stemedcoalition.org/wpco ntent/ uploads/2010/05/STEMEducation-Primer.pdf

Bisi, T.Y. (2012) Nigeria Schools and Science education. Lagos

Harri,D.(2011).Benefits of science education. Retrieved from http:// benefits of science education.

Emechebe, S.N. (2012).Achieving universal basic education in Nigeria: Issues of relevance, quality and efficiency. Global voice of Educators, 1(1),5.

Christine, A. \& Hayatu S, J.(2014). Universal basic education (ube) in nigeria problems and prospects in learning basic science in the upper 
basic : a case study of Kajuru local government area of Kaduna state.b

Future of Education Summit (2020) Problems of Science Education in Nigeria and Possible Solution https://www.summitexpo.com.ng/edu /2019/09/02/problems-scienceeducation-nigeria-and-possiblesolution.html

Musa, T. (2016). Effective Supervision in Basic Schools in Nigeria. Kano

Adelabu. (2005). Teacher motivation and incentives in Nigeria. Nigeria.
UNESCO (2009).UNESCO Institute of Statistics. Paris: UNESCO Press.

Ugo E,A \& Akpoghol, T,V. (2016) Improving Science, Technology, Engineering and Mathematics (STEM $\}$ Programmes in Secondary Schools in Benue State Nigeria: Challenges and Prospects. Asia Pacific Journal of Education, Arts and Sciences, Vol. 3 No. 3, Abubakar, S. (2015). Challenges facing Universal Basic Education in Nigeria. Abuja. 